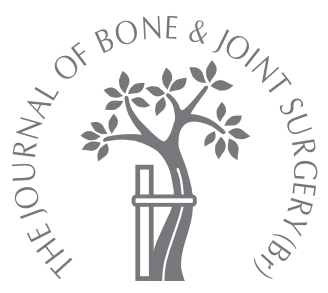

R. Lemaire

From University

Hospital, Liège, Belgium

R. Lemaire, MD, Honorary Professor

University Hospital (CHU du Sart-Tilman), 4000 Liège, Belgium.

Correspondence should be sent to Professor R. Lemaire at Rue du Centre 46, B-4130 Esneux, Belgium; e-mail:

roger.g.lemaire@skynet.be

(C)2008 British Editorial Society of Bone and Joint Surgery doi:10.1302/0301-620X.90B9. $21115 \$ 2.00$

$J$ Bone Joint Surg $[\mathrm{Br}]$ 2008;90-B:1128-36.
- ASPECTS OF CURRENT MANAGEMENT

\section{Strategies for blood management in orthopaedic and trauma surgery}

\author{
Several aspects of the management of an orthopaedic surgical patient are not directly \\ related to the surgical technique but are nevertheless essential for a successful outcome. \\ Blood management is one of these. This paper considers the various strategies available for \\ the management of blood loss in patients undergoing orthopaedic and trauma surgery.
}

Blood management is now receiving more attention, as shown by the increasing number of relevant publications over the past few years. ${ }^{1-5}$ There has thus been increased awareness not only of the amount of blood actually lost in common orthopaedic procedures but also of the possible disadvantages of allogenic blood transfusion, resulting in a general trend towards avoiding or minimising its use.

\section{Potential risks associated with blood transfusion}

Historically, correction of blood loss in surgical patients has been by transfusion of allogenic blood to maintain or to restore the haematocrit and level of haemoglobin $(\mathrm{Hb})$ close to normal. It is now accepted that the historical trigger values of $30 \%$ haematocrit and $10 \mathrm{~g} / \mathrm{dl}$ of $\mathrm{Hb}$ can safely be lowered to $8 \mathrm{~g} / \mathrm{dl}$ and even to $7 \mathrm{~g} / \mathrm{dl}$ of $\mathrm{Hb}$ in a patient with no major comorbidities. ${ }^{6}$ Experience with surgery on patients who are Jehovah's Witnesses has shown that mortality only becomes a major risk when the pre-operative $\mathrm{Hb}$ level is under $6 \mathrm{~g} / \mathrm{dl}^{7,8}$ and also that elective surgery such as total hip (THR) or knee replacement (TKR) can be performed safely without blood transfusion in non-anaemic patients who refuse blood transfusion. ${ }^{9}$

Other reasons contributing to the decline in the use of transfusion of allogenic blood include the effect on the immunological system, with various possible adverse consequences as follows.

A correlation has been reported between allogenic blood transfusion and post-operative infection in the elective surgical patient ${ }^{10-14}$ and even more so in the traumatically-injured patient. ${ }^{11,13}$ Leucocyte reduction by filtration has been found to reduce this effect without abolishing it. ${ }^{14} \mathrm{~A}$ number of countries have now opted for the general usage of leucocytedepleted blood in surgery. The association between the transfusion of non-leukodepleted allogenic blood and infection is being questioned, however, since its demonstration may have been biased for methodological reasons. ${ }^{15}$ Increased recurrence rates in patients with malignant tumours have been related to immunomodulation resulting from allogenic blood transfusion ${ }^{16,17}$ and other effects such as multiple-organ failure or mortality have been attributed to immunomodulation from allogenic blood transfusion by pro-inflammatory mechanisms. ${ }^{16-18}$

There is a risk of viral transmission of HIV, hepatitis C virus, and hepatitis $B$ virus although this has been dramatically reduced by the screening of donors and the development of efficient serological tests. In 2005, the risk was estimated at 0.31 per million blood donations for HIV, 0.10 per million donations for hepatitis $\mathrm{C}$ vrus and 1.44 per million donations for hepatitis B virus in France, ${ }^{19}$ with similar figures in the United Kingdom of $0.14,0.80$ and 1.66 per million donations for HIV, hepatitis C virus and hepatitis $\mathrm{B}$ virus, respectively. ${ }^{20}$ The possibility of the transmission of prions by allogenic blood transfusion has now been established in a small number of cases. ${ }^{21}$ The risk of bacterial contamination of blood products appears to affect platelet concentrates (1/50 000) much more than leukocyte-depleted erythrocyte concentrates $(1 / 500000) .^{22}$

Administrative errors in the handling of donated blood are rare but are occasionally responsible for major incidents which may be lethal. The risk applies to autologous blood transfusion also. In an evaluation of near-miss events in 35 French hospitals, Chiaroni et $\mathrm{al}^{23}$ 
found that in 407147 compatibility tests the incidence of ABO discrepancies was one in 3400 , which was related to phlebotomy errors or to registration and identification errors, but the incidence of $\mathrm{ABO}$ mismatched transfusion was ten times lower.

Allogenic blood transfusion also adds to the cost of an operation, all the more as it has been shown to be associated with increased morbidity and prolonged hospital stay. ${ }^{24}$

\section{Elements in the reduction of need for allogenic blood tranfusion}

A number of clinical studies ${ }^{1-5}$ have investigated ways of reducing the need for allogenic blood transfusion after orthopaedic operations while minimising post-operative anaemia. Most of these have focused on one specific action, such as pre-operative autologous blood donation, intraoperative cell saving, or re-infusion of drained blood. Blood management is a complex issue, however, and an integrated approach is necessary to address all its components.

Allogenic blood transfusion is required when a patient has lost more red blood cells than his/her condition would allow without endangering life. It is unavoidable in a number of patients after multiple trauma involving, for instance, complex fractures of the pelvis. In elective surgery, the risk can be evaluated well in advance, and a number of measures can be considered in order to reduce the probability of having to resort to allogenic blood transfusion. The key elements which should be taken into consideration are the pre-operative erythrocyte stock, the anticipated peri-operative blood loss and the acceptable blood loss for that specific patient.

Pre-operative erythrocyte stock. The pre-operative $\mathrm{Hb}$ level is the best predictor of the need for blood transfusion after various elective orthopaedic procedures. ${ }^{25-29}$ For primary THR or TKR the risk for the patient of requiring blood transfusion is virtually absent if the $\mathrm{Hb}$ level is $14 \mathrm{~g} / \mathrm{dl}$ or higher, and it increases as the pre-operative $\mathrm{Hb}$ level decreases. Patients with a pre-operative $\mathrm{Hb}$ level of $<13 \mathrm{~g} / \mathrm{dl}$ have a four times greater risk of having a transfusion than those with an $\mathrm{Hb}$ level between $13 \mathrm{~g} / \mathrm{dl}$ and $15 \mathrm{~g} / \mathrm{dl}^{27}$ With a pre-operative $\mathrm{Hb}$ level $<11 \mathrm{~g} / \mathrm{dl}$, the odds ratio for receiving transfusion is 13.92 compared with non-anaemic patients. ${ }^{29}$ A correlation has also been noted between theneed for transfusion and gender ${ }^{29}$ and body-weight, ${ }^{27-29}$ both of which are correlated with the blood volume, and also with advanced age $e^{28,30}$ and rheumatoid arthritis ${ }^{30}$ owing to the higher prevalence of anaemia. The erythrocyte stock of an individual is related to his or her blood volume and haematocrit. The blood volume in males amounts to $65 \mathrm{ml} / \mathrm{kg}$ to $75 \mathrm{ml} / \mathrm{kg}$ of body-weight and this is lower in females at $55 \mathrm{ml} / \mathrm{kg}$ to $65 \mathrm{ml} / \mathrm{kg}$ of bodyweight. The difference is related to the differing proportions of less well-perfused adipose tissue. Similarly, an obese male or female will have a smaller blood volume and erythrocyte stock than a lean individual of similar gender and weight.
Various formulae have been proposed to calculate with more precision the blood volume of individual patients, based on their height and weight. ${ }^{31,32}$ In a clinical setting, a simple calculation will give sufficient accuracy for clinical guidance. The erythrocyte volume is calculated from the estimated blood volume and the measured haematocrit. However, as already mentioned, the $\mathrm{Hb}$ level is a simple and convenient surrogate for the erythrocyte volume in evaluating the need for transfusion.

Anticipated blood loss. The total blood loss associated with an operation can be calculated from the decrease in the haematocrit and $\mathrm{Hb}$ level from the pre-operative values to those observed five to seven days after operation, taking into account any transfused blood, as well as the estimated blood volume of that specific patient. Blood loss includes several components. The external blood loss can be measured with reasonable accuracy and includes intraoperative and post-operative measurements, if the wound has been drained. The external blood loss is invariably smaller than the overall calculated blood loss. There is an internal blood loss which is referred to as the 'hidden' or 'occult' blood loss, which can also be calculated. ${ }^{33}$

It is now customary to report the total blood loss in clinical studies, while in the past only the external blood loss was described although there was often sufficient data to allow the total and hidden blood loss to be calculated. Based on such data, it appears that, if no specific bloodsaving measures are taken, the external blood loss after THR ranges between $830 \mathrm{ml}$ and $1460 \mathrm{ml}$, with a calculated total blood loss of between $1550 \mathrm{ml}$ and $2400 \mathrm{ml}^{34}$ The hidden blood loss thus ranges between $720 \mathrm{ml}$ and 840 ml. ${ }^{34}$ After total TKR the external blood loss ranges between $570 \mathrm{ml}$ and $1360 \mathrm{ml}$, and the calculated total blood loss between $1470 \mathrm{ml}$ and $2500 \mathrm{ml}$, corresponding to a hidden blood loss of $900 \mathrm{ml}$ to $1140 \mathrm{ml} .{ }^{34}$ The mean hidden blood loss represents $29 \%$ of the total blood loss after THR and $45 \%$ to $60 \%$ after TKR. ${ }^{33,34}$ The mean hidden blood loss after the surgical treatment of hip fractures was found to range between $547 \mathrm{ml}$ (screw fixation) and 1473 $\mathrm{ml}$ (intramedullary nailing). ${ }^{35}$

The hidden blood loss has sometimes been attributed to haemolysis, but there is no evidence for this, and scintigraphy using labelled erythrocytes has shown that it is essentially related to the extravasation of blood into the soft tissues. $^{36}$

The total blood loss may be higher after revision THR or spinal fusion (up to $2450 \mathrm{ml}$ ) or scoliosis surgery $(>3300 \mathrm{ml}) .{ }^{37}$ Blood loss is procedure-specific, and may also be surgeon- or institution-specific.

In everyday clinical practice, the estimated loss of blood and erythrocyte volume can be no more than a rough estimate, for a number of reasons. First, the patient's blood volume is estimated rather than measured, and the approximation therefore also affects the estimation of the pre-operative erythrocyte volume. Blood lost intra-operatively has, in theory, a haematocrit similar to the pre- 
operative value, although it may become increasingly lower if the patient is receiving large amounts of intravenous fluids in order to maintain normovolaemia. Blood drained post-operatively has a lower haematocrit, which also decreases since it contains an increasing proportion of exudate from the wound, as well as an increasing proportion of free $\mathrm{Hb}$ from haemolysis of the extravasated blood. This will nevertheless be listed as 'blood loss' although it should more correctly be characterised as 'bloody fluid loss'. If part of the blood drained post-operatively is re-infused after filtration, this will introduce a source of error in the calculation of total blood loss. Accuracy of the calculations can be improved to some extent by using the mean post-operative haematocrit of the patient. ${ }^{33}$ Secondly, there is often post-operative fluid retention for several days, which will lower the post-operative haematocrit while not reflecting the true loss of erythrocyte volume. Finally, if the patient has received a transfusion of red blood cell concentrates a source of error is introduced in the calculation of total blood loss since these 'red cell units' are usually considered to provide $200 \mathrm{ml}$ of red blood cells, although their volume may range between $250 \mathrm{ml}$ to $300 \mathrm{ml}$ with a level of haematocrit of between $55 \%$ and $80 \%$.

Evaluation of the anticipated blood loss should also take into account pre-existing anomalies of haemostasis, the intake of anti-inflammatory drugs and any factor which influences bleeding.

Acceptable blood loss. The amount of blood loss which a patient can tolerate depends to a large extent on his or her specific physiological features. An elderly patient with coronary heart disease will not tolerate blood loss as well as a younger healthy individual. Therefore, the minimum level of $\mathrm{Hb}$ and haematocrit which must be maintained postoperatively should be determined for each patient. For any given level selected, the permissable blood loss will thus depend on the estimated blood volume and pre-operative $\mathrm{Hb}$ level and haematocrit. If the anticipated blood loss is higher than the permissable blood loss, some action is necessary.

\section{Methods of reducing blood transfusion}

The need for allogenic blood transfusion may be reduced by various measures including the optimisation of the preoperative erythrocyte stock, the reduction of blood loss, the lowering of the transfusion trigger, the optimisation of the use of the patient's own blood and the use of 'blood substitutes'.

Optimisation of the pre-operative erythrocyte stock. The pre-operative erythrocyte stock seems to be the best predictor of the need for allogenic transfusion. It should therefore be evaluated sufficiently in advance to allow it to be augmented if necessary. It is estimated that approximately $20 \%$ to $30 \%$ of the patients who are to undergo THR or TKR are moderately anaemic and are at risk for tranfusion if no specific action is taken. ${ }^{29}$
Anaemia may be related to iron deficiency, reflected by a low level of plasma iron and elevated transferrin. In such cases, oral administration of iron is commonly prescribed, although it cannot be effective in the short term and is either inefficient, particularly in patients with inflammatory disease, or poorly tolerated in a number of cases. Intravenous administration of iron-sucrose has been used effectively in such cases ${ }^{38}$ and is gaining in favour, even in anaemic patients with no demonstrated iron deficiency. ${ }^{39,40}$ In anaemic patients who are not iron- or vitamin B12deficient, and in the absence of any possible source of chronic blood loss, the $\mathrm{Hb}$ level and haematocrit will only improve with the administration of erythropoietin, ${ }^{41}$ combined with oral or intravenous administration of iron. ${ }^{42}$ Different regimens have been tried in an attempt to achieve optimal cost-efficiency, and two have been advocated, namely, the daily administration of $300 \mathrm{U} / \mathrm{kg}$ body-weight for 15 days beginning ten days before surgery or the weekly administration of $600 \mathrm{mg} / \mathrm{kg}$ body-weight starting three weeks before surgery with one more injection on the day of surgery. ${ }^{43}$ Whichever is used, the erythropoietin must be combined with oral or intravenous iron administration. ${ }^{44,45}$ Reduction of peri-operative blood loss. This is possible by the attention to a number of details which are now described.

Any congenital or acquired predisposition to bleeding should be detected well ahead of surgery. This includes a variety of congenital conditions, some of which may remain undiagnosed until adult age, such as von Willebrand disease.

The intake of non-steroidal anti-inflammatory drugs (NSAIDs) or aspirin has been associated with increased blood loss. These drugs should be discontinued at least one week before surgery unless this would carry a serious risk in a patient with cardiovascular problems. ${ }^{46,47}$

Chemical thromboprophylaxis may also influence bleeding. Several meta-analyses have concluded that the risk of major haemorrhagic accidents is similarly low for lowmolecular-weight heparins (LMWH), vitamin K antagonists and aspirin, whereas unfractionated heparin gives a higher rate of major haemorrhagic problems. ${ }^{48,49}$ However, bleeding appears to be enhanced even with uneventful thromboprophylaxis using $\mathrm{LMWH} .^{28,48}$

The position of the patient may affect intra-operative bleeding. This is well known in spinal surgery. Bleeding during THR has been reported to be less with the patient in the lateral position than in the supine position, ${ }^{50}$ although a recent study has not confirmed this. ${ }^{51}$

Elevation of the lower limb after TKR has been shown to reduce post-operative blood loss. ${ }^{52}$

Controlled hypotensive spinal or epidural anaesthesia has been shown to reduce blood loss compared with general anaesthesia. ${ }^{53}$ Maintaining normothermia is also essential to avoid excessive bleeding. ${ }^{53,54}$ Pre-operative arterial embolisation is reserved for specific indications, such as complex pelvic fractures or surgery on highly vascularised tumours such as metastases from renal-cell 
carcinoma or aneurysmal bone cysts. Careful surgical haemostasis is recommended, with the occasional use of bone wax and surgicel when indicated.

Several studies have shown that post-operative bleeding can be reduced by half by using local haemostatic agents such as fibrin sprays. ${ }^{55,56}$ They have demonstrated their efficacy in a variety of surgical operations for more than 30 years. The limiting factor is essentially economic, owing to their high cost, although a low-cost locally-prepared fibrin glue has also been found to be highly efficient. ${ }^{57}$ Local application of platelet gel before wound closure is another option, and reduces bleeding after TKR. ${ }^{58}$ The topical use of tranexamic acid has also been shown to reduce blood loss after various operations such as coronary bypass ${ }^{59}$ or screw fixation of the lumbar spine. ${ }^{60}$

Systemic haemostatic agents have been used in an attempt to decrease blood loss and transfusion requirement. Desmopressin, a synthetic vasopressin-analogue, has been used with variable success in cardiac surgery. Several clinical trials failed to show any difference in blood loss and transfusion requirements when desmopressin was used in elective THR or TKR in haematologically normal patients. ${ }^{61-63}$ A Cochrane systematic review concluded that there was no convincing evidence that desmopressin reduced allogenic blood transfusion in patients who did not have congenital bleeding disorders. ${ }^{64}$ High-dose aprotinin, a fibrinolytic inhibitor, was found to reduce blood loss in primary and revision THR, TKR and spinal fusion. ${ }^{65-67}$ Its use has been limited because of its high cost and possible allergic reactions and a recently reported risk of acute renal failure. ${ }^{68}$ The worldwide sale of Trasylol (Bayer, Leverkusen, Germany) was suspended in 2007 pending the results of a trial to evaluate its benefit-risk ratio. Tranexamic acid, a synthetic fibrinolytic inhibitor, has been used for more than 20 years in various fields such as dentistry, gynaecology, cardiac surgery, urological surgery, and liver transplantation. Several studies have shown that it reduces total blood loss by nearly $50 \%$ and markedly reduces the need for allogenic blood transfusion after THR, ${ }^{69-71} \mathrm{TKR}^{72-74}$ and spinal surgery ${ }^{75,76}$ It is relatively inexpensive and does not appear to have any significant untoward side-effects. It did not increase the incidence of venous thrombosis in any of the clinical studies reported. ${ }^{77,78}$ For greatest efficacy it should be administered at the beginning of surgery, either as a continuous perfusion or as repeated bolus injections until a few hours after operation, because its half-life in the plasma is short. A comparative prospective, randomised controlled study showed a similar reduction in blood loss with the local application of fibrin spray and the intravenous administration of tranexamic acid. ${ }^{79}$ Similar beneficial effects have been reported with the oral administration of tranexamic acid before and up to 18 hours after TKR. ${ }^{80}$ Recombinant Factor VII has been found to be beneficial in controlling coagulopathic bleeding in massively bleeding surgical or trauma patients, but it has no indication in elective orthopaedic surgery ${ }^{81}$ since its cost is too prohibitive.
Many studies have investigated the possibility of reducing blood loss by not using wound drainage. Although wound drainage is an established tradition in orthopaedic surgery, there is considerable evidence to support its discontinuation in a number of common operations. ${ }^{82}$ In a recently updated meta-analysis, Parker et al ${ }^{83}$ concluded that there was insufficient evidence to support the routine use of closed suction drainage in orthopaedic surgery. Pooling data from randomised or quasi-randomised comparative studies, they failed to note any significant difference in the incidence of wound infection, haematoma, dehiscence or re-operations between drained and undrained wounds. Blood transfusion was required more often in patients who had drains, while bruising was more common in those without drains, who also needed more frequent dressing reinforcement. Differing results have been reported with respect to the effect of non-drainage on blood loss and transfusion rates, which is not surprising considering the number of variables involved, such as the number and diameter of drains, the type of suction used, the time to removal of the drain, and the concomitant use of LMWH or NSAIDs. The use of transfusion rates and volumes as outcome measures may also be biased by local differences in transfusion practice. Some authors have reported a reduction of blood loss and transfusion requirements after non-drainage, while others reported no difference. ${ }^{83}$ The avoidance of drainage reduces the external blood loss, but not necessarily the hidden loss, which may be increased, particularly after TKR. ${ }^{84}$ However, the overall balance appears to be towards a reduction in total blood loss. Practical details can make a real difference, such as an efficient padded compressive dressing which will reduce bleeding through a tamponade effect. This is common practice after operations on the knee, but it has also proved efficient at the hip. ${ }^{85}$

Various modifications in the drainage technique have been tested, such as delayed or intermittent drainage. These have usually resulted in a reduction in external blood loss by up to $50 \%$, but not in hidden loss. In one study on THR no reduction in external blood loss was noted after clamping the drain for the first two hours, ${ }^{86}$ while another reported marked reduction in external and total blood loss following intermittent clamping during the first six hours, with the drain opened for five minutes every hour. ${ }^{87}$ Among numerous trials on TKR only one reported no reduction in blood loss with clamping of the drain for the first two hours. ${ }^{88}$ Other trials showed a significant reduction in external blood loss using delayed drainage with the drain opened after one or four hours ${ }^{89,90}$ or intermittent drainage with the drain opened for five or ten minutes every one or two hours for the first six to ten hours. ${ }^{91-93}$ Delayed or intermittent drainage, as with non-drainage, relies on a tamponade effect. In other studies, delayed drainage was combined with the injection of $30 \mathrm{ml}$ or $50 \mathrm{ml}$ of saline with dilute adrenaline (1:200 000 to 1:1000 000) into the knee after TKR. This also effectively reduced the external blood 
loss. ${ }^{94-96}$ Problems of wound healing were noted only when adrenaline was left in situ for 24 hours. ${ }^{96}$ Infiltration of soft tissues with dilute adrenaline before closure is commonly used without similar adverse effects.

The usual justification for systematic wound drainage is the fear of encouraging the formation of deep haematoma if the wound is not drained. However, sonography and scintigraphy with labelled red blood cells have shown that haematomas and seromas will form anyway after removal of the drain. ${ }^{97,98}$ Drains should be removed after 24 hours, since $90 \%$ of the blood is collected within the first 24 hours and the limited amount of blood and/or exudate which could be collected thereafter would not balance the rising risk of retrograde infection. ${ }^{99}$

The use of the pneumatic tourniquet increases the comfort of the surgeon and is often instinctively perceived as improving cement fixation in TKR. However, it does not reduce the total blood loss and it may even increase it. ${ }^{100} \mathrm{~A}$ prolonged tourniquet time may induce a post-ischaemic reperfusion injury resulting in reactive hyperaemia and oedema. ${ }^{101}$ It may also stimulate fibrinolysis and increase the hidden blood loss. ${ }^{102}$

The timing of deflation of the tourniquet remains contentious. Deflation before wound closure tends to increase blood loss, ${ }^{103}$ while deflation after wound closure risks an occasional massive haematoma or haemarthrosis. Reinflating the tourniquet after surgical haemostasis tends to increase the severity of the subsequent re-perfusion syndrome, and also increases blood loss. ${ }^{104}$

Lowering the transfusion trigger. As already mentioned, the historical transfusion trigger of $10 \mathrm{~g} / \mathrm{dl}$ of $\mathrm{Hb}$ and $30 \%$ haematocrit can safely be lowered in most patients undergoing elective orthopaedic operations. Currently, accepted thresholds are $8 \mathrm{~g} / \mathrm{dl}$ of $\mathrm{Hb}$ in the older patient without severe comorbidities, and $7 \mathrm{~g} / \mathrm{dl}$ in the younger healthy patients. ${ }^{6}$ This should of course be tailored to the individual patient.

Optimisation of the use of the patient's own blood. This is possible using a variety of techniques.

Acute isovolaemic haemodilution presents, in theory, a number of advantages. Shed blood has a low haematocrit, which reduces red blood cell loss. Haemodilution enhances microcirculation. Autologous blood with active platelets and coagulation factors is re-infused and the risk of administrative error is virtually non-existent. However, it is a time-consuming procedure. Some patients tolerate acute blood withdrawal poorly and it also carries its own risks such as ischaemia if the target haematocrit is very low. In addition, there are the problems of re-transfusion of anaesthetic drugs and of haemostasis if extreme haemodilution is achieved. Hypervolaemic haemodilution does not involve any withdrawal of blood and is less time-consuming. ${ }^{105} \mathrm{It}$ has been found to have similar efficacy in reducing the need for allogenic transfusion in healthy adults, ${ }^{106}$ but it shares most of the disadvantages of isovolaemic haemodilution and can only be considered in young healthy individuals with efficient physiological compensation mechanisms.
A meta-analysis of 24 randomised trials concluded that the impressive reduction in allogenic blood transfusion reported in many instances may in fact be related to flawed study design. ${ }^{107}$ In a comparative study of the bloodsparing effect of tranexamic acid versus isovolaemic haemodilution, Zohar et al ${ }^{108}$ concluded that both were effective but that tranexamic acid appeared to be preferable because it was associated with superior haemodynamic stability and was also better in terms of blood sparing.

Pre-operative autologous blood predonation also offers a number of theoretical advantages. It has been widely used in the recent past, but has now fallen into relative disfavour for several reasons. ${ }^{109,110}$ It cannot reasonably be considered in patients who are anaemic, i.e. in $20 \%$ to $30 \%$ of patients who are to undergo THR or TKR, ${ }^{29}$ or in those with an $\mathrm{Hb}$ level $>14.5 \mathrm{~g} / \mathrm{dl}$ since they will not require blood transfusion. It should therefore be targeted to men with an $\mathrm{Hb}$ level of $11.0 \mathrm{~g} / \mathrm{dl}$ to $14.0 \mathrm{~g} / \mathrm{dl}$ and to women with a level of $13.0 \mathrm{~g} / \mathrm{dl}$ to $14.0 \mathrm{~g} / \mathrm{dl}$ whose anticipated perioperative blood loss is close to $1000 \mathrm{ml}$. In older patients who are not anaemic, the capacity of the erythropoietic marrow to react to the stimulus of blood withdrawal may prove to be inadequate. They may come to operation with an $\mathrm{Hb}$ level lower than that before pre-donation, and will need more transfusion episodes (autologous or allogenic) than they would have otherwise needed. For the same reason, many patients simply cannot complete the predonation programme because they become increasingly anaemic. The incidents and complications related to blood pre-donation are nearly 12 times as likely in autologous blood donors than in blood-bank donors, and they may be associated with significant morbidity. ${ }^{111}$

Pre-operative autologous blood predonation has been shown to reduce the absolute risk for allogenic blood transfusion by $43.8 \%$, but at the same time to increase the risk of any transfusion (allogenic or autologous) (relative risk: 1.29). ${ }^{109}$ The proportion of pre-donated blood which is wasted is high, up to $50 \%$ in some studies. ${ }^{12}$ However, Mercuriali and Inghilleri ${ }^{112}$ achieved a wastage rate of $<15 \%$ with customised prediction of transfusion requirements for the individual patient. It is generally accepted that pre-donated blood should not be re-infused in the absence of a clear indication and should also not be used for transfusion in other patients.

Brecher and Goodnough ${ }^{110}$ therefore concluded that "judicious use of pre-operative donation in concert with other blood conservation methods in specific cases remains appropriate; however automatic referral of all patients for pre-operative donation is oversimplistic and should be discouraged". An increasing number of studies comparing pre-operative donation and pre-operative administration of erythropoietin have concluded that the latter appears to be better with respect to the prevention of post-operative anaemia, while its cost-efficiency also appears to be superior when direct and indirect cost of pre-operative donation are taken into account. ${ }^{113,114}$ Pre-operative donation can 
also be combined with the pre-operative erythropoietin. This enables some patients to complete a pre-donation programme which would otherwise not have been possible, but this combination appears to be useful only when the anticipated blood loss is particularly heavy.

Another blood-saving procedure is peri-operative blood salvage. This includes re-infusion of blood drained within six hours after operation using cell salvage. Blood shed during operation may be altered by irrigation fluid, air and cement and should therefore be washed before re-infusion to avoid coagulopathy.

Peri-operative blood salvage has been shown to be beneficial in cases of blood loss exceeding $1000 \mathrm{ml},{ }^{115-117}$ but is not considered to be cost-effective in primary arthroplasty if other effective blood-saving measures have already been taken. Its use is generally restricted to specific indications in which the anticipated blood loss is very high, such as revision THR. Carless et $\mathrm{al}^{118}$ noted in their Cochrane Systematic Review that the use of cell salvage reduced the rate of allogenic transfusion by a relative $39 \%$ (relative risk 0.61 ), with a mean saving of 0.67 units of allogenic blood per patient. However, at least two units need to be recovered for the method to be cost-effective. In an extensive study on cost-effectiveness of various blood saving techniques, Davies et al $^{119}$ concluded that cell salvage (intra- and/or post-operative) had lower costs and gave slightly higher quality-adjusted life years than all of the alternative transfusion strategies except acute normovolaemic haemodilution. However, their analysis was not directed specifically at orthopaedic surgery. They suggested that post-operative reinfusion of unwashed cells may be more cost-effective than intra-operative salvage in orthopaedic procedures.

The available salvage and re-infusion systems use either washed or unwashed filtered cells. Most re-infuse unwashed cells after filtration and the specific features of the filter used in each system may result in the re-infusion of a variable amount of leukocytes and red blood cells. ${ }^{120}$ Blood re-infused after simple filtration has a low haematocrit and contains large concentrations of inflammatory mediators, histamine, eosinophil cationic protein, eosinophil protein $\mathrm{X}$, myeloperoxidase, plasminogen activator inhibitor type 1 , activated complement factor $\mathrm{C} 3$ and various coagulation factors and split products, ${ }^{121}$ as well as free $\mathrm{Hb}$. Despite this, post-operative re-infusion of unwashed filtered salvaged blood from drains appears to be safe, with no clinically important side-effects when a low volume of salvaged blood is returned. ${ }^{122}$ It is generally accepted that no more than $1000 \mathrm{ml}$ of drained blood should be re-infused, and also that blood drained more than six hours after the end of surgery should not be re-infused.

Post-operative cell salvage is not always cost-effective since the volume of blood recuperated is unpredictable. The reported mean volume of re-infused blood has ranged between $360 \mathrm{ml}$ and $880 \mathrm{ml},{ }^{123}$ relating to differences in surgical or drainage technique (drain number and diameter, vacuum pressure, etc); there are also marked variations among patients. ${ }^{123}$ The method is useful in patients with a small blood volume, as the likelihood of having to re-infuse more than $10 \%$ of their blood volume is high. ${ }^{123}$ It can be used in combination with other blood-saving measures ${ }^{124}$ if the anticipated blood loss is high, or in patients with a small blood volume and a low pre-operative $\mathrm{Hb}$ level. Most but not all studies ${ }^{125}$ on post-operative cell salvage have reported a reduction in allogenic transfusion rate and volume. ${ }^{126,127}$ Intra- and post-operative cell salvage are contraindicated in patients with infection and malignancy. The use of 'blood substitutes'. Since World War II, there has been a search for possible blood substitutes which would be readily available in emergency situations. The perfect 'blood substitute' should have an oxygen-carrying capacity similar to that of $\mathrm{Hb}$, should not require crossmatching, have a long shelf life as well as a long intravascular half-life, and be free from side effects. Two main types of possible blood substitute still in development have reached the stage of clinical investigation, namely perfluorocarbons and haemoglobin-based oxygen carriers ${ }^{128,129}$

Perfluorocarbons are biologically inert volatile fluids with a high dissolving capacity for $\mathrm{O}_{2}$ and $\mathrm{CO}_{2}$. They can transport and deliver oxygen by simple physical dissolution. Since they are not water-soluble, they are administered as emulsions stabilised by phospholipids, which can be sterilised. Their $\mathrm{O}_{2}$ carrying capacity depends on the concentration of perfluorocarbons, which varies between products.

Haemoglobin-based oxygen carriers are based on natural or recombinant human $\mathrm{Hb}$ or bovine $\mathrm{Hb}$, and are produced by various procedures including purification, encapsulation in synthetic phopholipid liposomes, crosslinkage and polymerisation in order to limit the possible side-effects of free $\mathrm{Hb}$. The clinical development of haemoglobin-based oxygen carriers has indeed been slowed down by adverse effects, including an increase in blood pressure by systemic vasoconstriction due to the scavenging of vascular endothelial nitric oxide, and oxidation, which generates methaemoglobin. Haemoglobin-based oxygen carriers have been tried in pre-clinical and clinical studies ${ }^{130,131}$ but no product has yet achieved market approval in Europe or the United States. One of the limitations of $\mathrm{Hb}$ solutions is their short intra-vascular half-life, and this is why they are intended to serve as a bridge to transfusion in emergency situations, rather than as definitive blood substitutes. There is no indication that they could be used in elective orthopaedic operations, at least in the near future.

\section{Conclusions}

Blood management is a complex issue, and most surgeons cannot be expected to have the necessary time and expertise to select from the numerous blood-saving techniques available to determine the optimal combination for each individual patient. Blood management should be made as simple as possible and should rely on common sense while also being cost-effective and having a low risk of complica- 
tions. Choices are made more complicated by the contradictory results reported with most blood-saving techniques. Critical analysis of the vast literature on blood management clearly shows the poor methodological quality of most studies. There are few prospective, randomised controlled studies, and frequent methodological flaws related to inadequate blinding and to the use of subjective outcome measures such as the rate and amount of allogenic blood transfused. With respect to transfusion policies there are major variations between institutions as there are with anaesthetics, surgical and wound-drainage techniques. Allogenic transfusion rates reported in the literature in the absence of specific blood-saving measures after TKR have ranged from $6 \%{ }^{132}$ to $95 \% .{ }^{133}$ In a study comparing blood loss after TKR with and without computer-assisted techniques, ${ }^{134}$ a mean blood loss of $1700 \mathrm{ml}$ in the drains was reported in the control group, a figure which would be found alarming by a number of surgeons with an interest in blood management, and the authors' conclusion that computer-assisted TKR reduces blood loss may not apply to patients managed using a different blood management policy. Similar scepticism also applies to the reported blood-saving effect of mini-invasive hip or knee replacement, for which the evidence appears to be very small. ${ }^{135}$

All meta-analyses of studies on blood management, including Cochrane Systematic Reviews, have reported that the level of evidence is low for most conclusions and statements in the literature. They invariably conclude that there is a need for large prospective, randomised controlled studies, but these may in fact never be done at all. Common sense therefore should prevail. Several easy safe and inexpensive measures can definitely help to reduce the rate and volume of allogenic blood transfusion. First, patients should be evaluated at least one month before surgery, to check their $\mathrm{Hb}$ and haematocrit levels, and to make sure that they do not have an increased risk of bleeding. The surgeon should then consider the anticipated blood loss, should be aware of the existence of a hidden blood loss, and estimate whether this is not higher than the allowable blood loss in each patient, which requires an evaluation of the erythrocyte stock. If the anticipated blood loss is higher, some action is necessary. Pre-operative blood donation has been used as a sort of panacea, but has often been found to be counterproductive since it may make the patient more anaemic and increase the risk for transfusion. Erythropoietin and iron administration now appear to be the best choice for patients with a $\mathrm{Hb}$ level $<11.0 \mathrm{~g} / \mathrm{dl}$ and an anticipated blood loss of $1000 \mathrm{ml}$ to $1500 \mathrm{ml}$ such as in primary THR or TKR. With a pre-operative Hb level at $12 \mathrm{~g} / \mathrm{dl}$ or $13 \mathrm{~g} / \mathrm{dl}$, simple measures such as the systemic administration of tranexamic acid, local application of fibrin spray, non-drainage of the wound or delayed and intermittent drainage, or post-operative cell salvage may be sufficient to avoid allogenic blood transfusion. These measures are not mutually exclusive and have all been found to be effective, although with the usual low level of evidence already men- tioned. In cases of high anticipated blood loss, preoperative blood donations may be considered, possibly combined with the administration of erythropoietin, in addition to all the other measures and with the addition of intra-operative cell salvage.

No benefits in any form have been received or will be received from a commercial party related directly or indirectly to the subject of this article.

\section{References}

1. Callaghan JJ, Spitzer A. Blood management and patient specific transfusion options in total joint replacement surgery. lowa Orthop J 2000;20:36-45.

2. Regan F, Taylor C. Blood transfusion medicine. BMJ 2002;325:143-7.

3. Keating EM, Meding JB. Perioperative blood management practices in elective orthopaedic surgery. J Am Acad Orthop Surg 2002;10:393-400.

4. Rosencher N, Kerkkamp HEM, Macheras G, et al. Blood management in elective knee and hip arthroplasty in Europe. Transfusion 2003;43:459-69.

5. Goodnough LT, Shander A. Blood management. Arch Pathol Lab Med 2007;131:695-701.

6. Carson JL, Willet LR. Is a hemoglobin of $10 \mathrm{~g} / \mathrm{dL}$ required for surgery? Med Clin North Am 1993;77:335-47.

7. Carson JL, Duff A, Poses RM, et al. Effect of anaemia and cardiovascular disease on surgical mortality and morbidity. Lancet 1996;348:1055-60.

8. Spencer RK, Carson JA, Poses R, et al. Elective surgery without transfusion: influence of preoperative hemoglobin level and blood loss on mortality. Am J Surg 1990;159:320-4.

9. Nelson CL, Stewart JG. Primary and revision total hip replacement in patients who are Jehovah's witnesses. Clin Orthop 1999;369:251-61.

10. Fernandez MC, Gottlieb M, Menitove JE. Blood transfusion and postoperative infection in orthopedic patients. Transfusion 1992;32:318-22.

11. Edna TH, Bjerkeset T. Association between blood transfusion and infection in injured patients. J Trauma 1992;33:659-61.

12. Bierbaum BE, Callaghan JJ, Galante J0, et al. An analysis of blood management in patients having a total hip or knee arthroplasty. J Bone Joint Surg [Am] 1999;81A:2-10.

13. Hill GE, Frawley WH, Griffith KE, Forestner JE, Minei JP. Allogeneic blood transfusion increases the risk of postoperative bacterial infection: a meta-analysis. J Trauma 2003;54:908-14.

14. Innerhofer P, Klingler A, Klimmer C, Fries D, Nussbaumer W. Risk for postoperative infection after transfusion of white blood cell-filtered allogeneic or autologous blood components in orthopedic patients undergoing primary arthroplasty. Transfusion 2005;45:103-10.

15. Vamvakas EC. Why have meta-analyses of randomized controlled trials of the association between non-white-blood-cell-reduced allogeneic blood transfusion and postoperative infection produced discordant results? Vix Sang 2007;93:196-207.

16. Vamvakas EC, Blajchman MA. Transfusion-related immunomodulation (TRIM): an update. Blood Rev 2007;21:327-48.

17. Landers DF, Hill GE, Wong KC, Fox IJ. Blood transfusion-induced immunomodulation. Anesth Analg 1996;82:187-204

18. Flohé S, Kobbe P, Nast-Kolb D. Immunological reactions secondary to blood trans fusion. Injury 2007;38:1405-8.

19. Pillonel J, Le Marrec N, Girault A, David D, Laperche S. Epidemiological surveillance of blood donors and residual risk of blood-borne infections in France, 2001 to 2003. Transfus Clin Biol 2005;12:239-46 (in French).

20. Soldan K, Davison K, Dow B. Estimates of the frequency of HBV, HCV, and HIV infectious donations entering the blood supply in the United Kingdom, 1996 to 2003. Euro Surveill 2005;10:17-19.

21. Hewitt PE, Llewelyn CA, Mackenzie J, Will RG. Creutzfeldt-Jakob disease and blood transfusion: results of the UK Transfusion Medicine Epidemiological Review study. Vox Sang 2006;91:221-30.

22. Blajchman MA. Incidence and significance of the bacterial contamination of blood components. Dev Biol (Basel) 2002;108:59-67.

23. Chiaroni J, Legrand D, Dettori I, Ferrera V. Analysis of $A B O$ discrepancies occurring in 35 french hospitals. Transfusion 2004;44:860-4.

24. Newman JH, Bowers M, Murphy J. The clinical advantages of autologous transfusion: a randomized, controlled study after knee replacement. J Bone Joint Surg [Br] 1997:79-B:630-2

25. Aderinto J, Brenkell IJ. Pre-operative predictors of the requirement for blood transfusion following total hip replacement. J Bone Joint Surg [Br] 2004;86-B:970-3.

26. Keating EM, Meding JB, Faris PM, Ritter MA. Predictors of transfusion risk in elective knee surgery. Clin Orthop 1998;357:50-9. 
27. Salido JA, Marin LA, Gomez LA, Zorrilla P, Martinez C. Preoperative haemoglobin levels and the need for transfusion after prosthetic hip and knee surgery: analysis of predictive factors. J Bone Joint Surg [Am] 2002;84-A:216-20.

28. Walsh M, Preston C, Bong M, Patel V, Di Cesare PE. Relative risk factors for requirement of blood transfusion after total hip arthroplasty. J Arthroplasty 2007;22:1162-7.

29. Saleh E, McClelland DB, Hay A, Semple D, Walsh TS. Prevalence of anaemia before major joint arthroplasty and the potential impact of pre-operative investigation and correction on perioperative blood transfusions. Br J Anaesth 2007;99:801-8.

30. Feagan BG, Wong CJ, Lau CY, et al. Transfusion practice in elective orthopaedic surgery. Transfus Med 2001;11:87-95.

31. Nadler SB, Hidalgo JU, Bloch T. Prediction of blood volume in normal human adults. Surgery 1962;51:224-32.

32. Mercuriali F, Inghilleri G. Proposal of an algorithm to help the choice of the best transfusion strategy. Curr Med Res Opin 1996;13:465-78

33. Sehat KR, Evans RL, Newmand JH. Hidden blood loss following hip and knee arthroplasty: correct management of blood loss should take hidden loss into account. $J$ Bone Joint Surg [Br] 2004;86-B:561-5

34. Lemaire R. Blood loss in orthopaedic and trauma surgery (in French). In: Duparc J. ed. Cahiers d'Enseignement de la SOFCOT, Elsevier, Paris 2003;82:247-61.

35. Foss NB, Kehlet H. Hidden blood loss after surgery for hip fracture. J Bone Joint Surg [Br] 2006;88-B:1053-9.

36. McManus KT, Velchik MG, Alavi A, Lotke PA. Non-invasive assessment of postoperative bleeding in TKA patients with Tc-99m RBCs. J Nuclear Med 1987;28:565.

37. Shapiro F, Zurakowski D, Sethna NF. Tranexamic acid diminishes intraoperative blood loss and transfusion in spinal fusions for Duchenne muscular dystrophy scoliosis. Spine 2007;32:2278-83.

38. Muñoz M, Breymann C, Garcia-Erce JA, et al. Efficacy and safety of intravenous iron therapy as an alternative/adjunct to allogeneic blood transfusion. Vox Sang 2008:94:172-83.

39. Auerbach M, Coyne D, Ballard H. Intravenous iron: from anathema to standard of care. Am J Hematol 2008;83:580-8.

40. Theusinger OM, Leyvraz PF, Schanz U, Seifert B, Spahn DR. Treatment of iron deficiency anemia in orthopedic surgery with intravenous iron: efficacy and limits: a prospective study. Anesthesiology 2007;107:923-7.

41. Laupacis A, Fergusson D. Erythropoietin to minimize perioperative blood transfusion: a systematic review of randomized trials. Transfus Med 1998;8:309-17.

42. Garcia-Erce JA, Cuenca J, Munoz M, et al. Perioperative stimulation of erythropoiesis with intravenous iron and erythropoietin reduces transfusion requirements in patients with hip fracture: a prospective observational study. Vox Sang 2005;88:235-43

43. Faris PM, Ritter MA. Epoetin alfa: a bloodless approach for the treatment of perioperative anemia. Clin Orthop 1998;357:60-7.

44. Johnson OC, Chebli C, Aboulafia AJ. Advances in therapeutics and diagnostics: epoetin alfa. J Am Acad Orthop Surg 2003;11:77-80

45. Earnshaw P. Blood conservation in orthopaedic surgery: the role of epoetin alfa. Int Orthop 2001;25:273-8.

46. Robinson CM, Christie J, Malcolm-Smith N. Nonsteroidal antiinflammatory drugs, perioperative blood loss, and transfusion requirements in elective hip arthroplasty. J Arthroplasty 1993;8:607-10.

47. Slappendel R, Weber EW, Benraad B, Dirksen R, Bugter ML. Does ibuprofen increase perioperative blood loss during hip arthroplasty? Eur J Anaesthesiol 2002;19:829-31.

48. Bong MR, Patel V, Chang E, et al. Risks associated with blood transfusion after total knee arthroplasty. J Arthroplasty 2004;19:281-7.

49. Haentjens $\mathbf{P}$, Lemaire $\mathbf{R}$. A pragmatic approach to prophylaxis of thromboembolic complications in orthopaedic surgery. In: Duparc J, ed. Surgical techniques in orthopaedics and traumatology. Elsevier, 2001:55-010-D-30.

50. Locher S, Kühne R, Lottenbach M, Bamert P. Blood loss in total hip prosthesis implantation: lateral versus supine position. Z Orthop Ihre Grenzgeb 1999;137:148-52 (in German).

51. Pace A, Yousef A. The effect of patient position on blood loss in primary cemented total hip arthroplasty. Arch Orthop Trauma Surg 2008 (in press).

52. Ong SM, Taylor GJ. Can knee position save blood following total knee replacement? Knee 2003;10:81-5.

53. Juelsgaard P, Larsen UT, Søorensen JV, Madsen F, Søballe K. Hypotensive epidural anesthesia in total knee replacement without tourniquet: reduced blood loss and transfusion. Reg Anesth Pain Med 2001;26:105-10.

54. Paul JE, Ling E, Lalonde C, Thabane L. Deliberate hypotension in orthopedic surgery reduces blood loss and transfusion requirements: a meta-analysis of randomized controlled trials. Can J Anaesth 2007;54:799-810.

55. Wang GJ, Hungerford DS, Savory CG, et al. Use of fibrin sealant to reduce bloody drainage and hemoglobin loss after total knee arthroplasty: a brief note on a randomized prospective trial. J Bone Joint Surg [Am] 2001;83-A:1503-5
56. Carless PA, Henry DA, Anthony DM. Fibrin sealant use for minimising peri-operative allogeneic blood transfusion. Cochrane Database Syst Rev 2003;2:CD004171.

57. Isarangkura $\mathbf{P}$, Chiewsilp $\mathbf{P}$, Chuansumrit $\mathbf{A}$, et al. Low cost locally prepared fibrin glue for clinical applications: reported of 145 cases. Commitee of Bangkok International Hemophilia Training Center. J Med Assoc Thai 1999;82(Suppl 1):49-56.

58. Everts PA, Devilee RJ, Brown Mahoney C, et al. Platelet gel and fibrin sealant reduce allogeneic blood transfusions in total knee arthroplasty. Acta Anaesthesiol Scand 2006;50:593-9.

59. De Bonis M, Cavaliere F, Alessandrini F, et al. Topical use of tranexamic acid in coronary artery bypass operations: a double-blind, prospective, randomized, placebocontrolled study. J Thorac Cardiovasc Surg 2000;119:575-80.

60. Krohn CD, Sørensen R, Lange JE, et al. Tranexamic acid given into the wound reduces postoperative blood loss by half in major orthopaedic surgery. Eur J Surg Supp/ 2003;588:57-61.

61. Flordal PA, Ljungström KG, Ekman B, Neander G. Effects of desmopressin on blood loss in hip arthroplasty: controlled study in 50 patients. Acta Orthop Scand 1992;63:381-5.

62. Schött U, Sollén C, Axelsson K, Rugarn 0, Allvin I. Desmopressin acetate does not reduce blood loss during total hip replacement in patients receiving dextran. Acta Anaesthesiol Scand 1995;39:592-8.

63. Karnezis TA, Stulberg SD, Wixson RL, Reilly P. The hemostatic effects of desmopressin on patients who had total joint arthroplasty: a double-blind randomized trial. J Bone Joint Surg [Am] 1994;76-A:1545-50.

64. Carless PA, Henry DA, Moxey AJ, et al. Desmopressin for minimising perioperative allogeneic blood transfusion. Cochrane Database Syst Rev 2004;1:CD001884.

65. Janssens M, Joris J, David JL, Lemaire R, Lamy M. High-dose aprotinin reduces blood loss in patients undergoing total hip replacement surgery. Anesthesiology 1994;80:23-9.

66. Kinzel V, Shakespear D, Derbyshire D. The effect of aprotinin on blood loss in bilateral total knee arthroplasty. Knee 2005;12:107-11.

67. Lentschener C, Cottin P, Bouaziz H, et al. Reduction of blood loss and transfusion requirement by aprotinin in posterior lumbar spine fusion. Anesth Analg 1999;89:590-

68. Okubadejo GO, Bridwell KH, Lenke LG, et al. Aprotinin may decrease blood loss in complex adult spinal deformity surgery, but it may also increase the risk of acute renal failure. Spine 2007;32:2265-71.

69. Husted H, Blond L, Sonne-Holm S, et al. Tranexamic acid reduces blood loss and blood transfusions in primary total hip arthroplasty: a prospective randomized double blind study in 40 patients. Acta Orthop Scand 2003;74:665-9.

70. Johansson T, Pettersson LG, Lisander B. Tranexamic acid in total hip arthroplasty saves blood and money: a randomized, double-blind study in 100 patients. Acta Orthop 2005;76:314-19

71. Claeys MA, Vermeersch N, Haentiens P. Reduction of blood loss with tranexamic acid in primary total hip replacement surgery. Acta Chir Belg 2007;107:397-401.

72. Benoni G, Fredin H. Fibrinolytic inhibition with tranexamic acid reduces blood loss and blood transfusion after knee arthroplasty: a prospective, randomised, doubleblind study of 86 patients. J Bone Joint Surg [Br] 1996;78-B:434-40.

73. Cid J, Lozano M. Tranexamic acid reduces allogeneic red cell transfusions in patients undergoing total knee arthroplasty: results of a meta-analysis of randomized controlled trial. Transfusion 2005;45:1302-7.

74. Camarasa MA, Ollé G, Serra-Prat M, et al. Efficacy of aminocaproic, tranexamic acids in the control of bleeding during total knee replacement: a randomized clinical trial. Br J Anaesth 2006;96:576-82.

75. Sethna NF, Zurakowski D, Brustowicz RM, et al. Tranexamic acid reduces intraoperative blood loss in pediatric patients undergoing scoliosis surgery. Anesthesiology 2005;102:727-32.

76. Neilipovitz DT. Tranexamic acid for major spinal surgery. Eur Spine J 2004;13(Suppl 1):62-5

77. Ho KM, Ismail H. Use of intravenous tranexamic acid to reduce allogeneic blood transfusion in total hip and knee arthroplasty: a meta-analysis. Anaesth Intensive Care 2003;31:529-37

78. Henry DA, Carless PA, Moxey AJ, et al. Anti-fibrinolytic use for minimising perioperative allogeneic blood transfusion. Cochrane Database Syst Rev 2007:4:CD001886

79. Molloy DO, Archbold HA, Ogonda L, et al. Comparison of topical fibrin spray and tranexamic acid on blood loss after total knee replacement: a prospective, randomised controlled trial. J Bone Joint Surg [Br] 2007;89-B:306-9.

80. Zohar $\mathbf{E}$, Ellis $\mathbf{M}$, Ifrach $\mathbf{N}$, et al. The postoperative blood-sparing efficacy of oral versus intravenous tranexamic acid after total knee replacement. Anesth Analg 2004;99:1679-83.

81. Rizoli SB, Nascimento B Jr, Osman F, et al. Recombinant activated coagulation factor VII and bleeding trauma patients. J Trauma 2006;61:1419-25.

82. Chandrateya A, Giannikas K, Livesley P. To drain or not drain: literature versus practice. J R Coll Surg Edinb 1998;43:404-6. 
83. Parker MJ, Livingstone V, Clifton R, McKee A. Closed suction surgical wound drainage after orthopaedic surgery. Cochrane Database Syste Rev 2007;3:CD001825.

84. Mengal B, Aebi J, Rodriguez A, Lemaire R. A prospective randomized study of wound drainage versus non-drainage in primary total hip or knee arthroplasty. Rev Chir Orthop Reparatrice Appar Mot 2001;87:29-39 (in French).

85. Johansson T, Enquist M, Pettersson LG, Lisander B. Blood loss after total hip replacement: a prospective randomized study betwen wound compression and drainage. J Arthroplasty 2005;20:967-71.

86. Clifton R, Norrish AR, Howell FR. Reducing blood loss after total hip arthroplasty: a prospective randomised controlled trial to evaluate the efficacy of temporarily clamping drains. Hip International 2005;15:108-11.

87. Brueggemann PM, Tucker JK, Wilson P. Intermittent clamping of suction drains in total hip replacement reduces postoperative blood loss: a randomized, controlled trial. J Arthroplasty 1999;14:470-2

88. Kiely N, Hockings M, Gambhir A. Does temporary clamping of drains following knee arthroplasty reduce blood loss?: a randomised controlled trial. Knee 2001;8:325-7.

89. Roy N, Smith M, Anwar M, Elsworth C. Delayed release of drain in total knee replacement reduces blood loss: a prospective randomised study. Acta Orthop Belg 2006; $72: 34-8$

90. Shen PC, Jou IM, Lin YT, et al. Comparison between 4-hour clamping drainage and nonclamping drainage after total knee arthroplasty. J Arthroplasty 2005;20:909-13.

91. Wittmann FW, Ring PA. Blood loss associated with Ring uncemented total knee replacement: comparison between continuous and intermittent suction drainage. $R$ Soc Med 1984:77:556-8.

92. Raleigh E, Hing CB, Hanusiewicz AS, Fletcher SA, Price R. Drain clamping in knee arthroplasty: a randomized controlled trial. ANZ J Surg 2007;77:333-5.

93. Prasad N, Padmanabhan V, Mullajo A. Comparison between two methods of drain clamping after total knee arthroplasty. Arch Orthop Trauma Surg 2005;125:381-4.

94. Ryu J, Sakamoto A, Honda T, Saito S. The postoperative drain-clamping method for hemostasis in total knee arthroplasty: reducing postoperative bleeding in total knee arthroplasty. Bull Hosp Jt Dis 1997;56:251-4.

95. Tsumara N, Yoshiya S, Chin T, et al. A prospective comparison of clamping the drain or post-operative salvage of blood in reducing blood loss after total knee arthroplasty. J Bone Joint Surg [Br] 2006;88-B:49-53.

96. Yamada K, Imaizumi T, Uemura M, Takada N, Kim Y. Comparison between 1-hour and 24-hour drain clamping using diluted epinephrine solution after total knee arthroplasty. J Arthroplasty 2001;16:458-62.

97. Varley GW, Milner S, Turner GM, Crisp AJ, Szypryt EP. Ultrasound assessment of the efficacy of wound drains. J R Coll Surg Edinb 1994;39:97-9.

98. Widman J, Jacobsson H, Larsson SA, Isacson J. No effect of drains on the postoperative hematoma volume in hip replacement surgery: a randomized study using scintigraphy. Acta Orthop Scand 2002;73:625-9.

99. Drinkwater CJ, Neil MJ. Optimal timing of wound drain removal following total joint arthroplasty. J Arthroplasty 1995;10:185-9.

100. Tetro AM, Rudan JF. The effects of a pneumatic tourniquet on blood loss in total knee arthroplasty. Can J Surg 2001;44:33-8.

101. Klenerman $\mathbf{L}$. Is a tourniquet really necessary for knee replacement? J Bone Joint Surg [Br] 1995;77-B:174-5.

102. Aglietti P, Baldini A, Vena LM, et al. Effect of tourniquet on activation of coagulation in total knee replacement. Clin Orthop 2000;371:169-77.

103. Hersekli MA, Akpinar S, Ozkoc G, et al. The timing of tourniquet release and its influence on blood loss after total knee arthroplasty. Int Orthop 2004;28:138-41.

104. Lotke PA, Faralli VJ. Orenstein EM, Ecker ML. Blood loss after total knee replacement: effects of tourniquet release and continuous passive motion. $J$ Bone Joint Surg [Am] 1991;73-A:1037-40.

105. Mielke LL, Entholzner EK, Kling M, et al. Preoperative acute hypervolemic hemodilution with hydroxyethylstarch: an alternative to acute normovolemic hemodilution? Anesth Analg 1997;84:26-30

106. Kumar R, Chakraborty I, Sehgal R. A prospective randomized study comparing two techniques of perioperative blood conservation: isovolemic hemodilution and hypervolemic hemodilution. Anesth Analg 2002;95:1154-61.

107. Bryson GL, Laupacis A, Wells GA. Does acute normovolemic hemodilution reduce perioperative allogeneic transfusion?: a meta-analysis. Anesth Analg 1998;86:9-15.

108. Zohar $\mathbf{E}$, Fredman B, Ellis $\mathbf{M}$, et al. A comparative study of the postoperative allogeneic blood-sparing effect of tranexamic acid versus acute normovolemic hemodilution after total knee replacement. Anesth Analg 1999;89:1382-7.
109. Henry DA, Carless PA, Moxey AJ, et al. Pre-operative autologous donation for minimising perioperative allogeneic blood transfusion. Cochrane Database Syst Rev 2002:2:CD003602.

110. Brecher ME, Goodnough LT. The rise and fall of preoperative autologous blood donation. Transfusion 2002;42:1618-22.

111. Popovsky MA, Whitaker B, Arnold NL. Severe outcomes of allogeneic and autologous blood donation: frequency and characterization. Transfusion 1995;35:734-7.

112. Mercuriali F, Inghilleri G. Proposal of an algorithm to help the choice of the best transfusion strategy? Curr Med Res Opin 1996;13:465-78.

113. Keating EM, Callaghan JJ, Ranawat AS, Bhirangi K, Ranawat CS. A randomized, parallel-group, open-label trial of recombinant human erythropoietin vs preoperative autologous donation in primary total joint arthroplasty: effect on postoperative vs vigor and handgrip strength. J Arthroplasty 2007;22:325-33.

114. Stowell CP, Chandler H, Jove M, Guilfoyle M, Wacholtz M. An open-label, randomized study to compare the safety and efficacy of perioperative epoetin alfa with preoperative autologous blood donation in total joint arthroplasty. Orthopedics 1999;22(Suppl 1):105-12.

115. Gargaro JM, Walls CE. Efficacy of intraoperative autotransfusion in primary total hip arthroplasty. J Arthroplasty 1991;6:157-61.

116. Schmied H, Schiferer A, Sessler DI, Meznik C. The effects of red-cell scavenging, hemodilution, and active warming on allogenic blood requirements in patients undergoing hip or knee arthroplasty. Anesth Analg 1998;86:387-91.

117. Slagis SV, Benjamin JB, Volz RG, Giordano GF. Postoperative blood salvage in total hip and knee arthroplasty: a randomised controlled trial. J Bone Joint Surg [Br] 1991;73-B:591-4

118. Carless PA, Henry DA, Moxey AJ, et al. Cell salvage for minimising perioperative allogeneic blood transfusion. Cochrane Database Syst Rev 2006;4:CD001888.

119. Davies L, Brown TJ, Haynes S, et al. Cost-effectiveness of cell salvage and alternative methods of minimising perioperative allogeneic blood transfusion: a systematic review and economic model. Health Technol Assess 2006;10:1-210.

120. Moonen AFCM, Pilot P, Meijers WGH, et al. Filters in autologous blood retransfusion systems affect the amount of blood cells retransfused in total knee arthroplasty: a pilot study. Acta Orthop Belg 2008;74:209-15.

121. Andersson I, TyIman M, Bengtson JP, Bengtsson A. Complement split products and pro-inflammatory cytokines in salvaged blood after hip and knee arthroplasty. Canad J Anesthes 2001;48:251-5.

122. Muñoz M, Cobos A, Campos A, et al. Impact of postoperative shed blood transfusion, with or without leucocyte reduction, on acute-phase response to surgery for total knee replacement. Acta Anaesthesiol Scand 2005;49:1182-90.

123. Pitsaer E. Transfusion of recuperated blood in total knee arthroplasty. Rev Chir Orthop Reparatrice Appar Mot 2002;88:777-89 (in French).

124. Xenakis TA, Malizos KN, Dailiani Z, et al. Blood salvage after total hip and total knee arthroplasty. Acta Orthop Scand Supp/ 1997;275:135-8.

125. Keating EM, Ritter MA. Transfusion options in total joint arthroplasty. J Arthroplasty 2002;17:125-8.

126. Newman JH, Bowers M, Murphy J. The clinical advantages of autologous transfusion: a randomised, controlled study after knee replacement. J Bone Joint Surg $[\mathrm{Br}]$ 1997;79-B:630-2

127. Sturdee SW, Beard DJ, Nandhara G, Sonanis SV. Decreasing the blood transfusion rate in elective hip replacement surgery using an autologous drainage system. Ann R Coll Surg Eng/ 2007;89:136-9.

128. Spahn DR, Kocian R. Artificial 02 carriers: status in 2005. Curr Pharm Des 2005;11:4099-114.

129. Smani Y, Labrude P, Vigneron C, Faivre B. Hemoglobin-based oxygen carrier and trials to substitute red blood cells. Transfus Clin Biol 2007;14:464-73 (in French).

130. Gould SA, Moore EE, Hoyt DB, et al. The life-sustaining capacity of human polymerized hemoglobin when red cells might be unavailable. J Am Coll Surg 2002;195:445-52.

131. Levy JH, Goodnough LT, Greilich PE, et al. Polymerized bovine hemoglobin solution as a replacement for allogeneic red blood cell transfusion after cardiac surgery: results of a randomized, double-blind trial. J Thorac Cardiovasc Surg 2002;12:35-42

132. Jones AP, Harrison M, Hui A. Comparison of autologous transfusion drains versus no drain in total knee arthroplasty. Acta Orthop Belg 2007;73:377-85.

133. Majkowski RS, Currie IC, Newman JH. Postoperative collection and reinfusion of autologous blood in total knee arthroplasty. Ann R Coll Surg Eng/ 1991;73:381-4.

134. Kalairajah Y, Simpson D, Cossey AJ, Verrall GM, Spriggins AJ. Blood loss after total knee replacement: effects of computer-assisted surgery. J Bone Joint Surg [Br] 2005;87-B:1480-2.

135. Woolson ST. In the absence of evidence: why bother?: a literature review of minimally invasive total hip replacement surgery. Instr Course Lect 2006:55:189-93. 